\title{
ダイ・ルー族住居の基本的な架構形式について

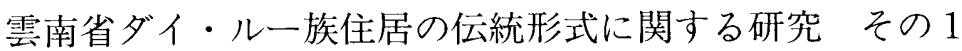

THE BASIC STRUCTURAL STYLE IN DWELLINGS OF DAI-LU

A study on dwellings of Dai-Lu in Yunnan Part 1

高野恵子*

Keiko TAKANO

A minority group Dai-Lu has wooden settled dwellings. Recent years their dwellings have several varieties of style, however it is possible to reconstruct the typical dwelling tentatively from the common building techniques seen in the modern dwellings. This supposed basic structural style is;

1) The 14 Main Pillars (Irigawa-bashira) make a rectangular area which is two bays by five. They receive 6 beams and 2 purlins.

2) Two ridge-bearing pillars (Munamochi-bashira, supporting a ridgepole directly) stand at the center of the rectangular interior.

3) The 14 perimeter pillars (Gawa-bashira) surround the three sides of the rectangular area, and 8 thin poles (Kabe-tsuka, supporting outside-walls) stand along the rest of the side.

KeyWords : Dai Lu, settled dwelling, structural style, Irigawa-Bashira, Munamochi-bashira, Gawa-bashira ダイ・ル一族, 高床式住居 架構形式, 入側柱, 棟持柱, 側柱

1.はじめに

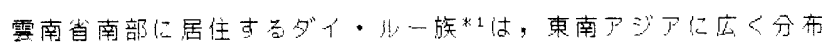

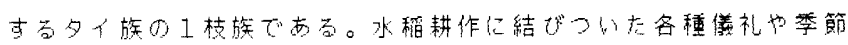

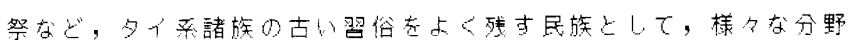
で研究が為さ机てきた。喷らの居住声る高床式住居估, 東南Pジア

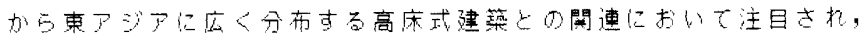
特经日本の建筑学分野では，日本との開連において近年注目を集め， 多くの紹介や研究加為さ机ている。

建筑学分野での研究では，現在一船的に見ることのできる住居形

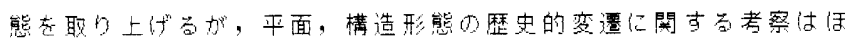

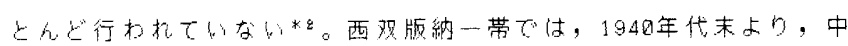

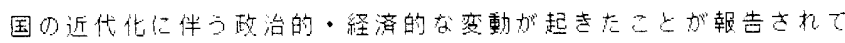
お口*3，末右本研究の調查地周辺では，197日年代初頭に大規模な住 居建造ラッシュが起こつ去上伝えられる*4。現在見ることのできる 住居のほとんどが，近代化以降，特に1970年代以降に建造されたも のであり，そ机前の住居形態から变化したものであると把える゙ きである。

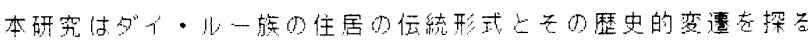
ことを目的々する゙怔，本稿では，近代化以前(特に1970年代の建造 ラッシュ以前)に存在した一般的な住居形態を類推する手がかり上
して, 架構形態に注目し，考察在倠める。現在見るさとのできる住 居の架構形態考分析し, 近代化以前化成立していた, 基本上なる架 構形式在明らかによ上うと者ものである。

2. 対象地域と住居の一般的状況について

本稿で対象とする鲃罕鎮*5近隣の村落では軸部，造作共に木造で，

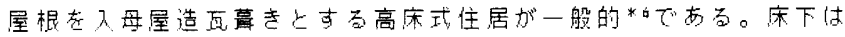
倉庫幏音小屋上しで用いられ，人加生活の場とするのは床上に限

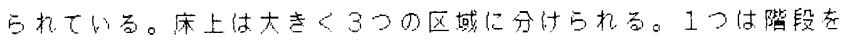
登った位置にある半外部空間( 以下庇空間)で,ここでは日常的な作 業在行う。2つは庇空間から入省居室で，中央に囲炉裹加置か力，

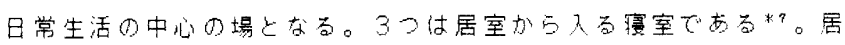
室と寝室は，概して楝木の直下に桁行方向纪立てられ仕切り壁で 区切的机ている。

現在胃ら机录往居のほとんどは建造されてから20年以内のもので 古る。一船に住居の寿命は短く，約1日年ほどで建て替えられ*日，そ

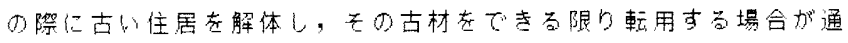
例である*a。建造後3日年以上を経た住居は珍しく，一つの村落に数 棟しか見受けられな上に，近年の建造で仙既存住居の平面，架構

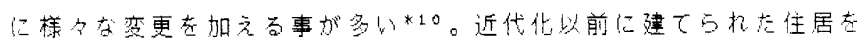




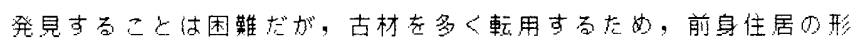
態を比較的容易に推測できるものは多く発見される*い。

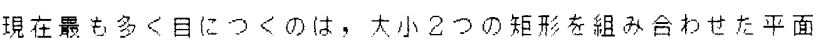

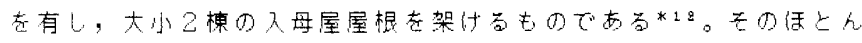
どはここ1日年ほどの間に建てら报もので，2棟住居に住杂家族の

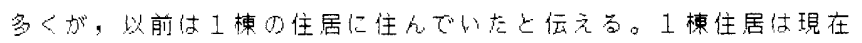

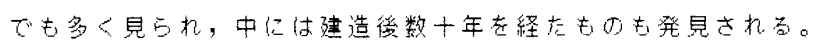

本稿では架構形式の検討のため，最も些純架構形態を有する1

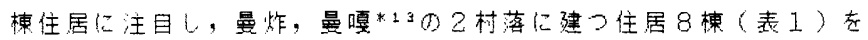
採り上げ，分析奆進める。

3.用吾等について

本稿で用いる住居の䝷料は，全て現地調查で得られたたのに基づ

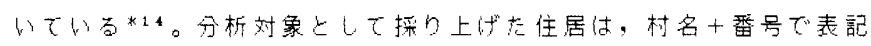

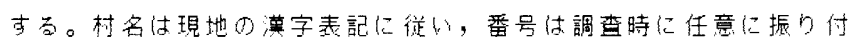
けた。

部材名はなるべく日本建筑の用語に従い，日本語化したものを用

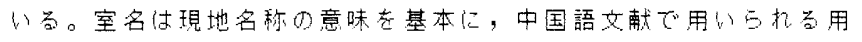
語を参考として日本語化したもの老用いる*15。

\section{4.古い住居の概要}

显炸20は建造後50年以上を経をもので，現在まで架構解体を行っ

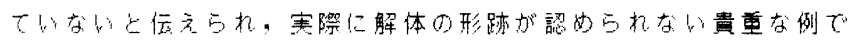
西当(图1・图2)。

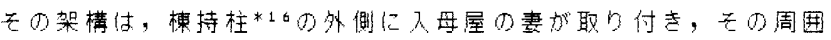
を背の高い入侧柱*17が取り卷き, その外侧に側柱*1タが巡る, 上屋 ・下屋構造となっている。下屋外の二方には更に庇が付設される。 久側柱は璴石から上屋梁までの一材で，床下で整ぎ買くン・本 一)，大引貫(キャン)で絴横侣連結され，高床上方に内法貫(夕 ソ・ホ一)*19が入る。柱頍は上屋梁(ク一・ロン)，桁(ビエ）を 載せ宓, 折置き組上同様の架構となる。6本の上屋梁のうち, 図中

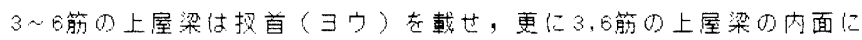
接七て棟持柱加立てら机て，投首上楝持柱々で棟木支える。 崩に立つ报首の誃面に妻壁(ヅゥ・フー)が吊り下げられる。

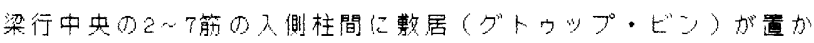

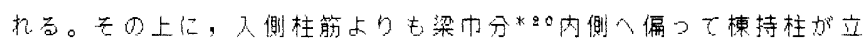

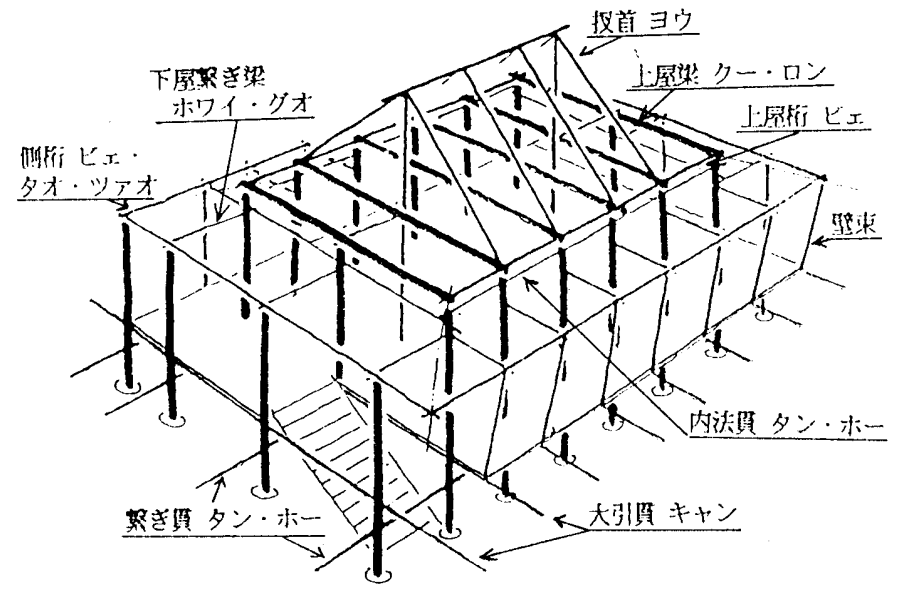

因1:曼炸20架棈概念园

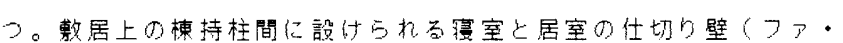

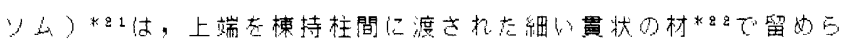
れる。敷居直下には入側柱筋に床束怔立てられる。床束の上端の大 引貫は，頍貫様の收まりになっているたか，整居は床束上大引貫で 支えられる。床束は周囲の人側柱在貫通する慗ざ貫上大引貫によっ て連結されている。

側柱俚入側柱より背が低く，礎石から側桁(ビエ・タオ・ッアオ） までの一材で茜る。床下で入側柱老貫通す当繋ぎ貫, 大引貫が通さ れ，高床上で側柱頂上の下屋繋ぎ梁（ホワイ・グ才）によって人側 柱亡連結する。側柱は入側柱の四周老巡らず，入口側，奥，居室側 の3方に立つ。侧柱外面纪接して大引貫の上に床緑材が置加れ，を の上に上方が多へ傾いた(以下外転び)細い壁束が立つ。壁束は，小

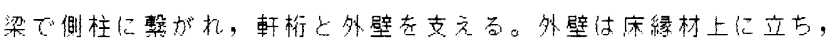

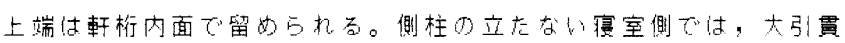
の上に置かれた床緑材の上に，前述の細い壁東柱と同じ材が立ち倒 桁と外壁を支えるが，ここでの小梁は入侧柱に大入れで熟がれる。 多壁の上端は側桁の内面で留妨ら机てい各。瘄室側の軒桁は, 同様 の細い壁束を立てて支えられる。この壁束は, 床縁材の外側, 入側 柱から庇柱八渡された賈状の材の上に立つ。ここに壁は入らない。

屋根は上屋・下屋娄一つとし, 庇屋根は独立して切り下代る。平 側は力垂木(ルン) を上屋梁上に立てられ荾瀷首の中程上り側へ向 かって架计，上屋桁上側桁に載世各。もの上に楝加巨薄いゴヒラの

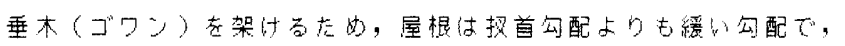

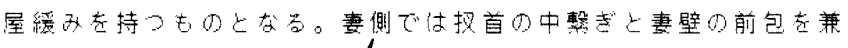

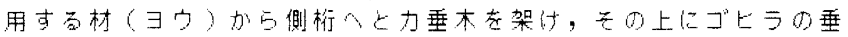

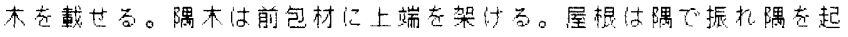
己すため，側桁の高さは梁行桁行で微妙に異なる。

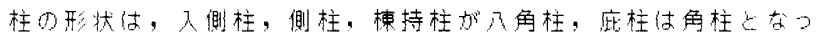

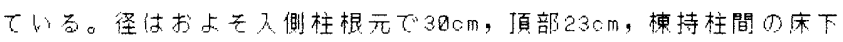

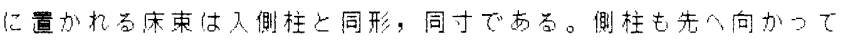
細くなり，根元で $25 \mathrm{~cm}$, 頂部で18cmとなる。棟持柱は径が一定で約 $18 \mathrm{~cm}$, 庇柱も上下に抎り径が一定で西るが, 柱每のばらつきが激

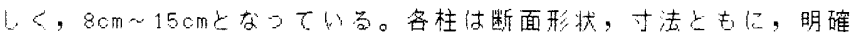
に区分して用いられていることが窥われる。

以上老まとめると，䔬炸200柱配置は，2本の棟持柱の周囲老14

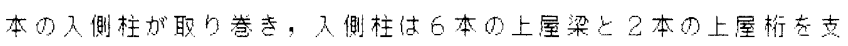

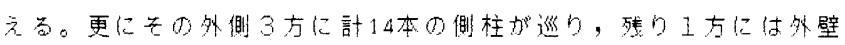
を支えると同時に側桁を支える細い壁東加8本並ぶもので满る。

\section{5. 入罚柱について}

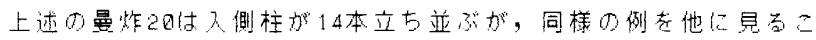
とは困蜼である。ここで近年に建诰された住居の入側柱配置に注目 し, 比較在行方。

曼炸28(圆3)は新䇥の例で，任とんどの入側柱が立たかい。居室

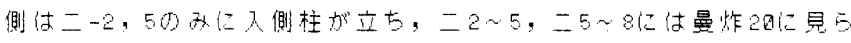

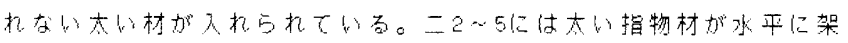
计られ，両端が入㑡柱に掸される。指物上のニ-3,4に沈入側柱上部 と同様の径上形状考もつた短心束が立ち, 上屋梁老克之。一方, ニー5〜8に架けられた材は 7 筋までは水平だが，そこから”へ字形に 下方へ折机曲がって端部在側柱に直接載せる。ここでは前者党指物 


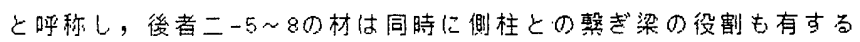
た奻, 大梁と呼ぶ*8。また指物上に载る, 入側柱と同径, 同形状の 短い束を短束と低称し，二-2 5の水平の指物を入れる技法を(1)，二 -5 80大梁を入机当技法を(2)として論を進める。

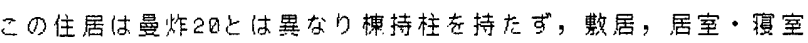
の仕切り壁が棟木直下よりも漫室側に後退している。同時に，㵊空 側に入侧柱が立たず，侧柱が立つ。棟木は曼炸20と同様に上屋梁上 に置かれた投首で受けられる他，3，6筋の上屋梁上に立つ棟束で支え られる。棟木筋加らずれ在仕切り壁の立つ又八列では, 又八4，5を除 き，入側柱と同形状の柱功立ち，壁を支えると同時に上屋梁を支え る。また又八3〜6に技法(1)で指物が渡され，その上の又八4,5に短束

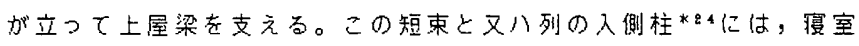
側へ梁行方向に，技法(2で大梁が架けられる。大梁の上口列に，二 列, 又八列で見られるものと同様の短束が立ち，上屋梁を載せる。 従つて入側柱本数が少ないながらも，上屋梁は靦炸20上同様に6本 が数えられる。

近年の新筑である㯰嗄16亿图4)では，ニー6，ロ-3に入側柱が立た ず，二-5 7，口-2 4に技法(1)で指物が入れられる。曼炸28と同様 に指物上に短束を立て上屋梁老載せるため，上屋梁は同様に6本が 数えられる。

曼炸34(图 5) 既存住居を一㭙解体して再建したもので, ニ-4,6，

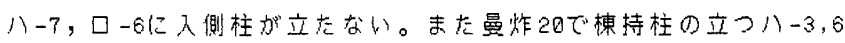
に入側柱と同梯の柱加立って上屋梁老載せ，上屋梁の上に投首と共 に棟束が立てられる。ニ-3〜 7, ロ-5 7には技法(1)で指物が渡され， 短束在立てて上屋梁在受ける。二-5には入側柱が立つ加，その上端 は上屋梁まで達せずに二ー3〜 7に渡された指物を直接支える。その上 に立つ短束は, 表面の材色也鉋痕淿上り，かつては1本の入側柱で 西つたものを再建に直たつて切断し，用いたものと考えられる。ま たハー6〜8にも技法(1)で指物が渡されその上に短束を立てるが，ここ での指物は側柱までの水平材として用いられ，背の高い短束を载せ る。上屋梁は㬅炸20と同様に6本を数える。

いずれの例でも短束は必ず入倒柱上部と同じ径を持ち，入唰柱と 同様に八角形に整形されている。古材を多く転用している畏炸 34 は 当然としても，新材を用いる鲱嗄16および曼炸28においても，歪 を持つものの，短束在八角形に整形している点は，入侧柱と短束と の深い關連を示唆していると考えられる。また梁行柱筋で, 両側の 入側柱が共に立奆ない場合であっても，入側柱の立つべき位置に短 束を立てて上屋梁を載せ，上屋梁を常に6本としている*8。このこ とは，本来，入側柱加1列に6本並ぶ架構が基本的な形式であった こと在示しており，従って短束は，拻き取られた入側柱の痕跡であ ると把えることができる。

短束を入側柱の痕跡であるとすれば，罬炸34の梁行中央間八-7短 束も，入側柱の痕跡と考えることができる。また居室・温室の任切 り壁が寝室側に偏る曼炸28では，仕切り壁が偏つた專に伴って柱列 が又八列に移動したものと把えられ，又八-2,7は入側柱，又ハ-3,6 は曼炸2日に見る棟持柱の痕跡であると考えられる。更に短東の立つ 位置の床下には，必ず床束が立てられている点からも，入倒柱の痕 跡を認めることができる。

以上より，近代化以前に遡ることのできる基本的な架構形式は， 入側柱が14本立って矩形を描き，6本の上屋梁が架计られるもので
あると考えることができる。

\section{6. 棟持柱について}

現在見られる住居で，棟持柱を有する例は稀であり，棟持柱也棵 束老全く持たないものが大半を占放る。特に棟持柱老持つ例は，現 在29棟の資料の中で 3 棟(曼炸20，曼炸27(图6)，曼嗄16)に過ぎな い。いずれの例も入側柱の形状より，基本となる架構形式がよく現 れていると考えられる住居であるが，ここに見られる棵持柱の存在 が，より古層に遡る形式か否かは疑問が残る。不明な点も多いが， 現時点で確認される範囲での棟持柱に関わる問題を整理すると以下 のょうになる。

(1)曼炸2㩐の襕持柱は, 双首構造との併用であるため構造的に不必 要なものである。また，棟持柱が床束に載せられた敷居上に立てら れた束柱の形状を取り，更に入侧柱に置かれるような護符布*27が置 かれないことから，棟不を支える独立柱としての棟持柱という，本 来の棟持柱の構造的，形態的な形式が形䯓化したものであると把え ることも可能である。

(2)同じ棟持柱を持つ建造物として，村落に建つ寺院仏殿*2aが挙げら れる。仿殿の屋根架構は，小屋束と小屋梁を重枚た小屋組架構であ るため, 棟持柱もしくは橧束は必須である。小屋組を用いる寺院仏

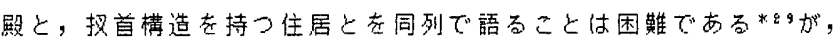
住居の棟持柱は，寺院の棟持柱との関連を思わせる。

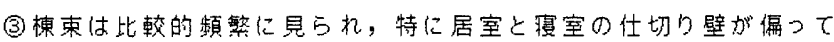
いる住居では頻繁に見られる。曼炸20のように楝持柱が立つ例と比 較すれば，㫫炸28などに見られる棟束は，棟持柱の形䯓化したもの と把えることができる。棟束は，棟持柱のあるべき位置に架付られ た上屋梁の上に立てられるが，同じ梁上に投首が立つため，束は内 側へ徯退せざるを得ない。最も頻繁に見られるものは，棟束に15x $7 \mathrm{~cm}$ 程の材を用い，投首の盤ぎ材内面ぎりぎりに立てるものである。 この時の棟東は角材が用いられており，入側柱を抜き取つたときの 短束が常に八角形に整形されているのに比べ，「柱」としての形状 が希薄である。

以上より，本来の形式では棟持柱が存在していなかった可能性が 指摘できるが，一方相反するように，

(1)棟束の形状が柱としての形状を有していない例があると同時に， 意識的に棟持柱の形態を残したと考之られる例も存在する。近年の 再建である曼炸34では上屋梁下に入側柱と同様の形状を持つ柱が立 ち，上屋梁上には八角に整形された細い棟束が立つ。ここに用いら れた柱，棟東はともに新材であると判断され，おそらく1980年の再 建時你挴入されたと見られるものである。

(2) 疅炸28に見られる棟束は薄い束であるが，又八3，6に立つ入側柱は 棟持柱の痕跡と見做すことができる*30。

以上よりダイ・ルー族の住居にとって，棟持柱の存在が，古い 時代にまで遡ることのできる架構形式であることには疑問が残る。 しかし現存する住扂から考察する限り，2本の柇持柱が曼炸20と同 様の形態で立つものが，ある時期に普遍的であったことは否定でき ない。疁炸20および27の建造年代加ら推定して，1940年代の近代化 以前での基本的な架構形式は，2本の棟持柱を持つものであり，こ の形式が現在の住居の直接の基本形であると考えられる。 
7.缴柱と外壁について

現在村落に見られる住居のほとんどが，外壁を外転びとする*3。 その壁估，大引貫上に運かれた库緣材の上に立てられた壁束によつ て支えられる。壁束は柱と小梁によって迪結されるため，壁束は柱 筋纪立つ。

曼炸20では，入侧柱の3万に側柱が14本立ち亚ぶ。側柱のある位 量では，壁東は側柱から伸びる小梁と力垂木，軒胻で支えられ，大

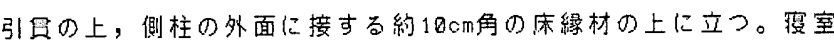
側の側柱の立たない位圈では，壁束は入側柱から伸びる小梁と力垂 木，側桁で支えられるが，壁束の脣さは側柱の立つ位还にある壁柬 と同じであるた市，外転び勾配が变化する。壁束の立つ床緑材は， 大引賁の上に直接置かれる他，端部は梁行方向の床緑材に择される。

一方近年の新筑である曼炸28では，側柱は計18本で四周を巡り， ホー3のみに立たない。外壁は曼炸20と同様，床緣材の上に立つ壁束 によって支えられ，上部が外へ傾いている。壁束上端は側柱から伸 びる小梁と力垂木，側桁で支えられ，側柱のないホー3では力重木と 倒桁で上端を支える。床緣材はいずれも側柱外面に按し，桁行方向 の床緑材は大引貫の上に直接哉り，梁行方向の床緑材は桁行方向の 教居の上に端部を戴せる。

曼炸20，曼炸28の側柱と外壁との関係は同じものである。曼炸20 では，寝室側の胻行方向の壁の收まりが，側柱がないことによって 他と異なる収まりとなっていることに対し，㩖炸28では四周とも同 一手法で壁加立てもれ，合理的であるとも把えられる。しかし入側 柱を省略しても床束と短束が入側柱の痕跡を示していたのに対し， 曼炸20の寝室側の側柱筋には側柱の痕跡が認められず, 側柱が四周 を巡る形態が基本的なものであるとは断定できない。

瘦室の使い方に注目すると，曼炸20では仕切り壁から久側柱の間 に，入側柱を枕側として布団を歌き延べ，入側柱より外側には私物 を入れた長持を圈く。曼炸20と同栏寝室内に入侧柱の立つ例では， 全て同様に入侧柱内側に布団を数き，入側柱外側には長持や篮简を 遭く*a。

一方仕切り壁が偏る曼炸28では，仕切り壁から側柱の間一杯に布

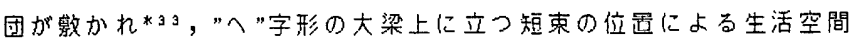
の便い分けは認如られない*34。これは入側柱の消失によって布団を 教き延べる筑囲の指標が失われ，その結果，側柱を入側柱のように 取り损うようになったた内と把えられる。また，仕切り壁〜側柱(外 壁)間を一杯に使えるようになると，充分な部屋巾を確保することが 容易となり，居室・㿉室の仕切り壁加䌸室侧へ偏ることを可能とし たのであろう。その結果，大梁の室外側端部を堅牢に支えるために 側柱が必票となったと考えられる*35。

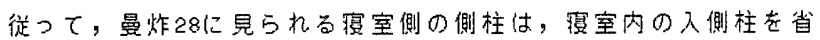
略したために必要となった柱であると理解される。曼炸20に見られ る入侧柱の3方に側柱が 14 本立方，1方は 8 本の壁束で側桁を支え るものが，現在の住居から推定される，近代化以前に遡ることので きる基本的な架榜形式であると考えられる。

\section{8.まとや}

以上より，現在見られるら゙イ・ルー族木造住居の基䃈となった基 本的な架構形式は，2本の棟持柱を有し，その周囲を14本の入側柱 が取り巻き，更にその3方を合わせて14本の側柱と8本の壁束が取
り巻くという上屋・下屋構造であると考察される。曼炸20にこの架 楎形式加最も良くみられ，近年の新筑もしくは改筑による住居の架 構形態は, 㽗炸20のヴァリエーションであり, 本稿で明らかにした 基本的な架構形式を簡略化したものと把えることができる。

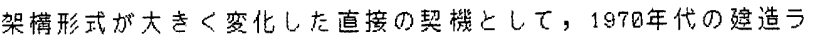
ッシュが考えられる。ラッシュ以降に建造された新筑もしくは改筑

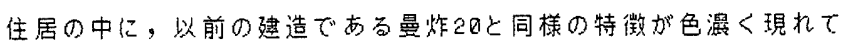
いることは, 曼炸20亿現れ架榜形式が, 意嬨的に保持ざれていた ことを示している。従つて，本稿で明らかにした，曼炸20に見られ る架棤形式は，当時に於ける伝統形式であると把えることができる。

本稿はダィ・ル一族木造住居の, 近代化以前に遡る架榙形式につ いて考察を試みたが，より古層に遡る架構形式を示唆するものとし て，镍持柱の問題や，現在でも村落に見られる竹を多用した住居の 検討などが挙げられる。また，住居全体の伝統形式を明らかにする た内には, 室内外の様々な装置と平面形態に關する調查, 検討が必 要である。更に，近年の再建もしくは新筑による平面变化の形態と， そ机に伴う生活形態の变容など，近代化に伴う变化在分析すること

\section{も重要である。}

以上の上うにダイ・ルー族の住居形式を理解する上で桎された 課題は多く，資料の充実を計ると共に考察を深め，住居の伝統形式 を明確にしていきたい。

敦;

${ }^{1}$ Thai Lu，またはDai Lu。中国表記侇湖」。夕イ，ラオス，ベトナム，ビルマ・シャ ン州，アッサム，中国南部に広く分布し，言語的にはタイ語族を榜成するタイ系諸

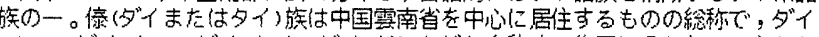
・ルー,ダイ・ナーダイ・タイタダイ・ドンなどと自称する集団に分かれる。主とし

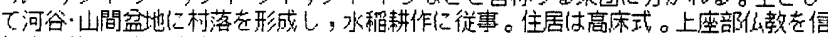

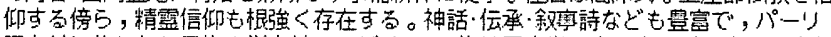
語を基に作られた居族文学を持つ。ダイ・ルー族は露南省，虹州省などの中国西南部

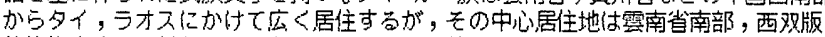
納儫族自治州。首都景洪(ジンホン)。西观版納はダイ語でトシップソン・パン・ナ」と

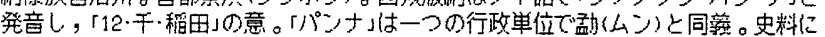

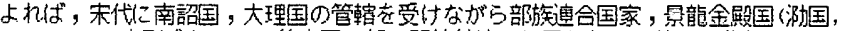

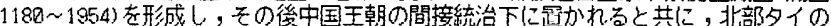
ラーン・ナー王国，北部ラオスのラーン・サーシ王国と算密な閶係を持ち続けた。ダ イ・ルー族を含むダイ族の歴史，文化，生活一船については多くの報告が為されてお

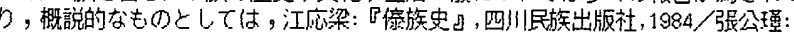
『函族文化研究』,零南民族出版社, 1988 ，などが学げられる。

*2溉南省周边の諸民族を包括的に扱い，比較考察しながらダイ族を取り举げるものと

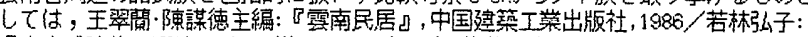
『䯩床式迲物の源流』,弘文堂, 1986など。ダイ族住居を中心として取り扱うものに

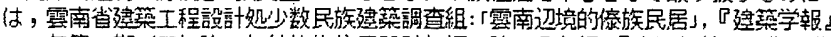
1963年第11期/王加強: 「伝統诼族住居䛇計初探，陸元鼎主編，『中国伝統民居與文化 一中国民居学術会議論文集』，中国建筑工菜出版社, 1981/曾文照: 『中国焉南儫族民

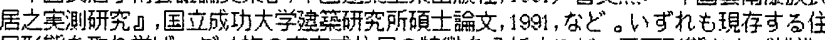

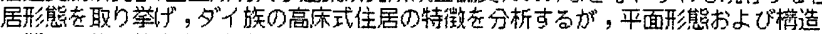
形態上の復原的考察は行われていない。若林弘子1986および曾文照1991では, 住居 の訜計寸法および䛇計方法に言及するが，現存する多䱋住居の各部寸法花指摘する

に留まり，徼原的考察を行うものではない。また，しばしば㥜銅器文化滨・ドンソ

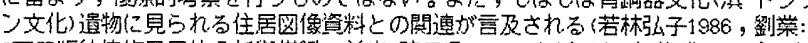
「西双版納绿族民居的分析與借鑑」，前出·陸元鼎1991，などが，年代ギャップが大き すぎ，末た青銅器文化の坦、手がダイ・ル一族の直接の先祖である確証も得られない ため,いささか直感的な論であると产わざるを得ない。㖹筑学分野での既往研究の

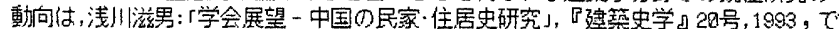
網薾的经概説さ机ている。

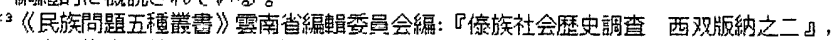

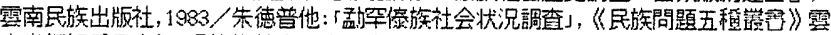

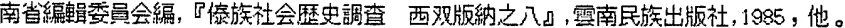

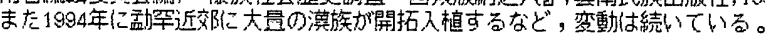

*4現地調榃での間き取り調查による。䋟じて住居の建造年代は，家人によって極めて

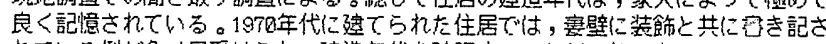

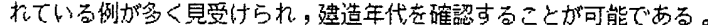

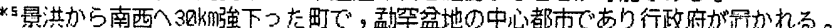

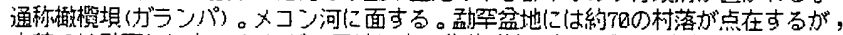

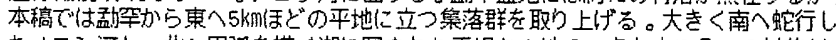
たメコン河と, 北へ丹弧を描く湖に囲まれた平坦な土地で, 点在する5つの村落が

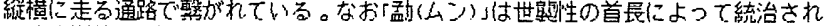
る政治単位,「甼ママンク」村の意。

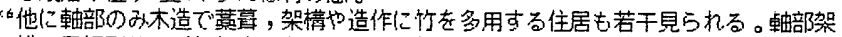
槽，屋根形状など類伿点は多いものの，規模が小さく瞇主を持たない等，基本的な 相殡点も多い。このタイプの住居に闗しての考察は後に淁りたい。 
*. 註15参照

${ }^{k 4} 4$ 力村，9名の大工加らの聞き取りによる。竹を多用した住居の場合はおよそ3年と

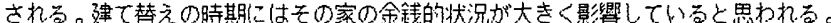
建て替えの契䊾は家主の交替結婚等の家族構成員の变化によるものと，腐朽や歪 みなどの構洁的な問題によるものとに大別できる。

*9前身住居の古材だ什ではなく，不要となった他の住属の古材も利用される。ほとん どの家では数年後の新算に向け少しづつ材を眝藏していくが，その中にはかなりの

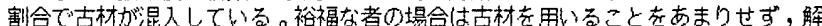
体して出る古材を売り抬うこともあるという。本来多人旗は周辺の森林より自由に 木材の伐採加でき志が，文革後森林は国有林とされ，伐採(十困難となった。また中 国全体で木材が高腾しているために新材が手に入りにくいという状況も影響してい 夸と思独る。

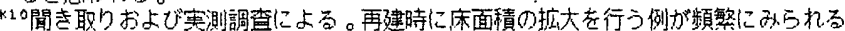

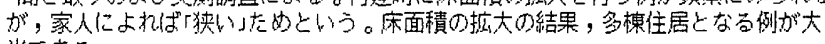
半である。

*11 1棟住居，多棟住居ともに発見できる。曼炸27，曼炸34等は1棟住居の例。本稿で

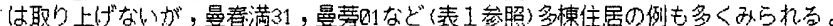
《12およそ80\%が2棟形式の住居で，既往研究で取り挙げられるのはほとんどがこの形 式である。屋根形状は棟を平行に並べるものと，L字型に直行させるものとが見ら れる。他に了棟住居も見られる。1棟住居は，村落によって割合がかなり畏なるが， 10～20\%释度存在する。なお゙゙イ・ルー族の住居では，平面の形状と屋根形状とが密

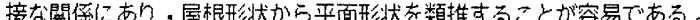

*13村人からの間き取りによれば各村沿革，規棋は以下の通り。

曼怍: 成立時期诗不明だが，現存寺院(1982年再建)の前身建物はかか心古いものて あったと伝えられる。現存最古の住居(曼炸20)は建造後52年以上を経るという。19 93年現在, 46 戸, 人口244人。

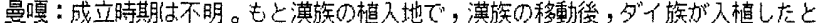
いう。入植より1 2世代加経過。1993年現在, 23戸，人口120人程度。

*14 1991.3 4, 1993.3 4,1995.2 3に䒠施。1996年1月現在での住居平面実測資料は

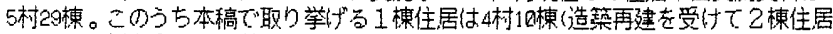
となった2例を含む)。詳細は表1参照。

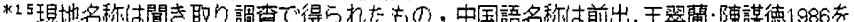

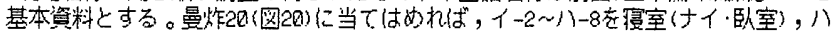

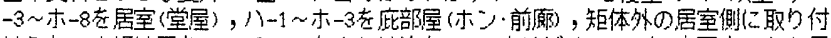
けられる水場如露台(シャン・唒台または涼台)。()内はダイ・ルー名・中国名。なお居

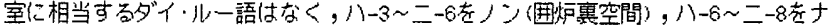

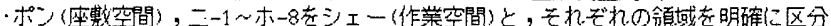
する装置を持たず，柱位置を手がかりとした䌊やかな領域設定を行う。それぞれの 異なった役㓯を担うものの，日中の生活に用いる空間である点で共通すると共に，

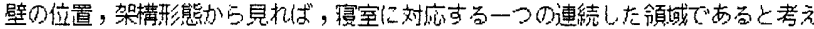
ることができる。本稿では架棤形態こついて論を進めるため，上記3空間を一つの

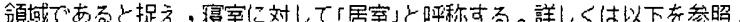

高野恵子: 「雲南省西观版納のダイ・ル一族住居に関する五研究」、『日中伝統民家・集落

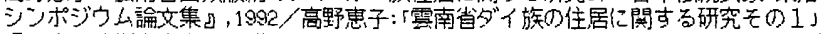

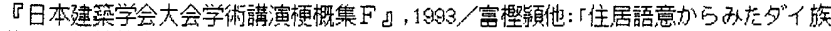
住居の伝統的空間構造(その1，2）－西双版納夕゙イ族の住居·集落に関する研究一」,

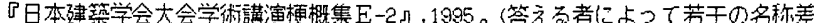

異が出ることは，本研究調查でも富榴他1995でも確認さ机ている。また露台を「ツア うょと記述するなど, 聞き手の違いによる日本語表記に差異が見られる。本稿では簐 者の用いてきた呼称夺㑑先して用いる

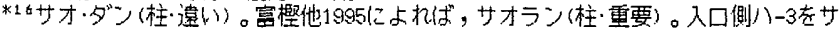

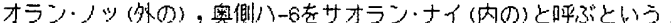

*17それぞれで名称が異なる。ロ-2=サオ・ジェン・ベイ・ノッ(柱・終・つまたたはサオ・テ インダイ(柱・階段)，ロー5ニサオ・ナン(男柱)またはサオ・ディウフラ・ヘン(柱・神・家)，

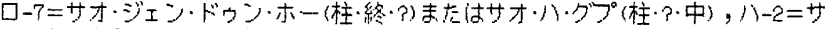
オ・ガングプ・ベイ・ノッ(柱·中央・?，ハ-7ニサオ・ガングプ(柱·中央)，二-2=サオ

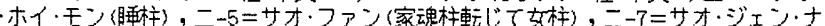

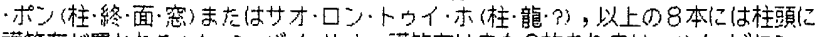

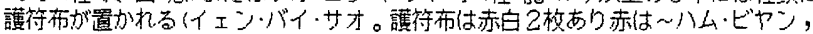
白は〜ハムハオり。その他の柱は八ー2,7の柱と合わせてサオ・ガングつ゚と呼称される
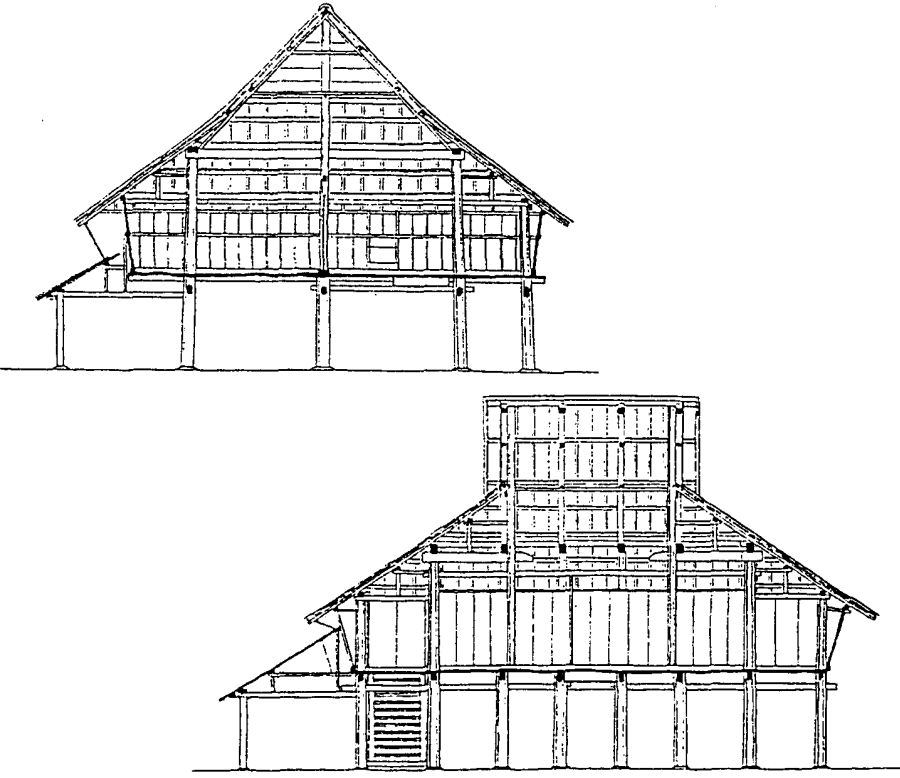

場合も古る゙，無名であるともいう。各入側柱の名称は，ロ-5，二-5侅中で最も大 事とされるい外は答える者によっで混乱する。若年層ではほとんど名称老知らない

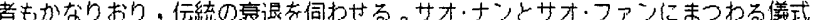

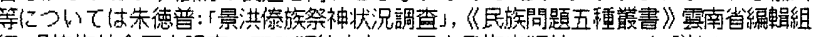

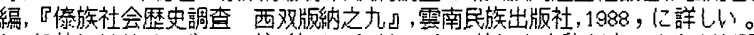

*16一般的にはサオオジェン柱・終と呼ぶという。他にも名称があるようだが濞時点で は未整理。サオ・ジェンという呼称の正確さま未確認である。

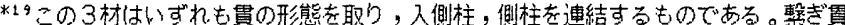
と内法貫はどちらもタン・ーと呼ばれ，原㝨は撃ぐ・貫」。前者は床下の大引貫の 下方で桁行方向に入れられるもの，後者は床上の柱䌿部に近い部分で，桁行，梁行 両方に入れられるものであるため，現地名が同じながら，ここでは違う名称老用い る。大引貫(キャン)は，床直下に梁行方向に入る貫で，床板下の根太と，後出の敷

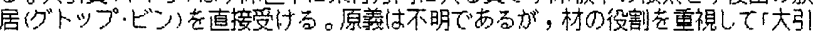
貫」上呼称する。

*8\%およ入㑡柱径半分に相当する。

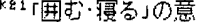

*28撃ぎ貫，内法貫と同じくタン・ホーとされるが，楧造材としての意味をほとんど持 たず，材の形状も缼ざ貫，内法貫と異なる。別名の可能性もあるが現時点では不明。 *83両者上も, 固定し大現地名称はない。

*\&4棟木の位置からずれるため，篇密には入側柱とは呼べないが，同じ形状の部材在用 いているため敢えて入側柱と呼ぶこととする。

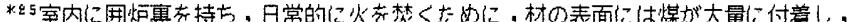
材の新旧の判別は容易である。また材の整形加工は主に鉈を用い，チョウナの溙な はつり痕夺表面に㙛す。加工は目分量で行わ机るたばらつきが影しく，そのため 切断分割された材の得原は比較的容易である。

*86同様の例はごく一船的に見られる。1棟住局では，曼炸28のように居室·幔室仕切

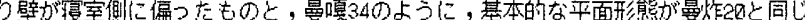
ものとの2種類が見られるが，いずれの場合も技法(1)で短束を立て，上屋梁は 6 本を数える。また 2 棟住居では，完全新筑のもの上，既存住居老大棵として小棟を 造筑し芯ものの2種に分かれるが, どちらの場合も大棟の上屋梁は6本を数える。 *87註17参照。9名の大工からの聞き取りに上れば，棟持柱は「特別な柱てであるため通

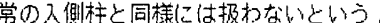

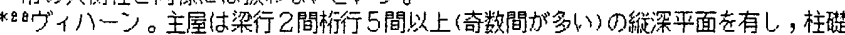
上に立つ太6主屋柱は切妻屋根老支える。屋根架構は小屋組で，急勾配，强以屋緩 み存持つ。棟持柱の位置は，住居で入側柱列の内側に立つのに対し，伀殿では入倒 柱列上に立つ。徉つて入側柱と棟持柱は矩形老描き，その上部には切嘦屋根を架け 高。棟持柱方しはばしば両脇の入側柱よりも内側入偏って立てられる点は住居と同様 である。側柱は入側柱と槙持柱の四周を巡り，切り下げられた疪が架けられる。

*899名の大工加少閒き取りによれば，寺院を建诘する大工は住居大工から区別され ており，数も少ない。調榃地近隣に寺院大工は居らず，必要な時には遠方から呼び 奇せるという。調查で出会つた大工靯!全て住居尃門の大工であり，寺院の建造の 手法や手順を尋犳ても，知識のある者はいない。

*30前项5. 入侧柱につい 2 , 参照。

*31夕イ族では外壁が外転びとなるのが一般的であり，袙数の報告が為されている。深 い軒，開口部の少ない形状と合独て，陽光存遮り，通風を良くするための形状で

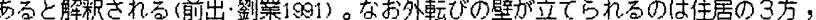
析行方向の壁と, 居室奥の壁のみで，人口側の側柱荕には壁は立をない。人口側では

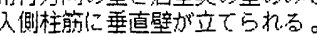

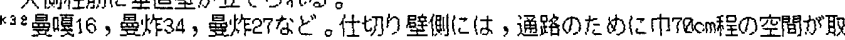

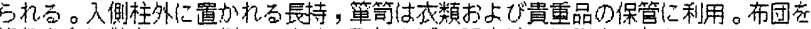
桁行方向に敷き延べる例は，本稿で取り上げ䒘調查地では認めら机ない。

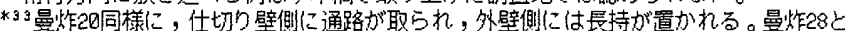

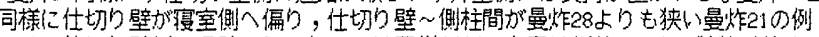

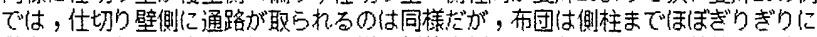
㪙き延べられるため，長持は布团の横，側柱内側に㯰かれている。具体的な寸法は 表1に記載。

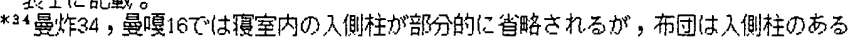
場所々同様，入側柱位置の内㑡こ敷き姃べられることと刘照的である。

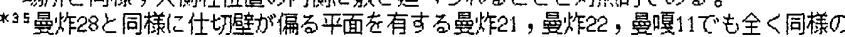
手法を用いる。

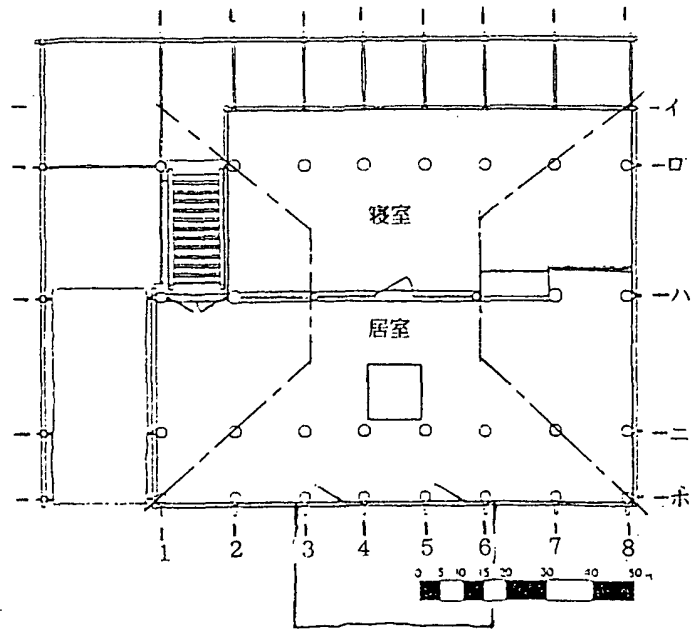

図2:曼炸 20 平・瞇面图 

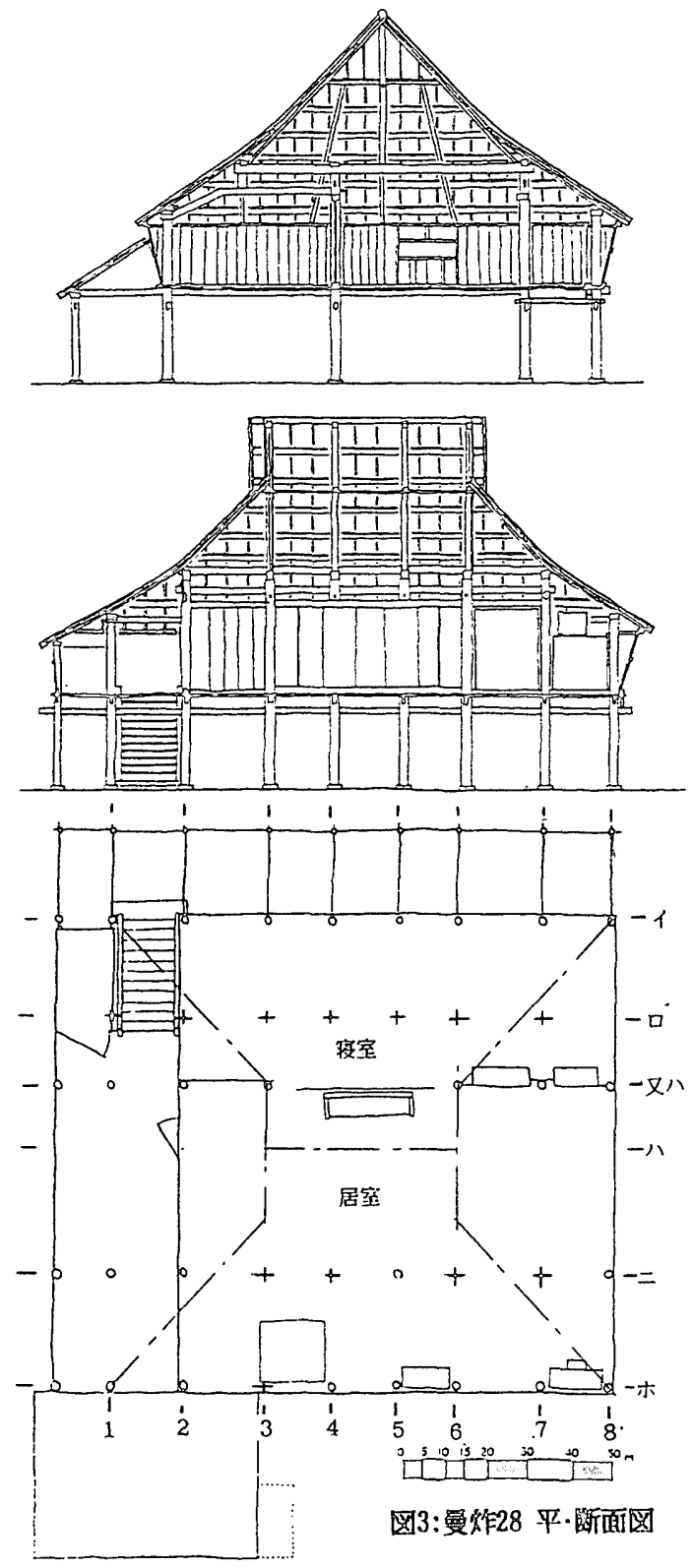

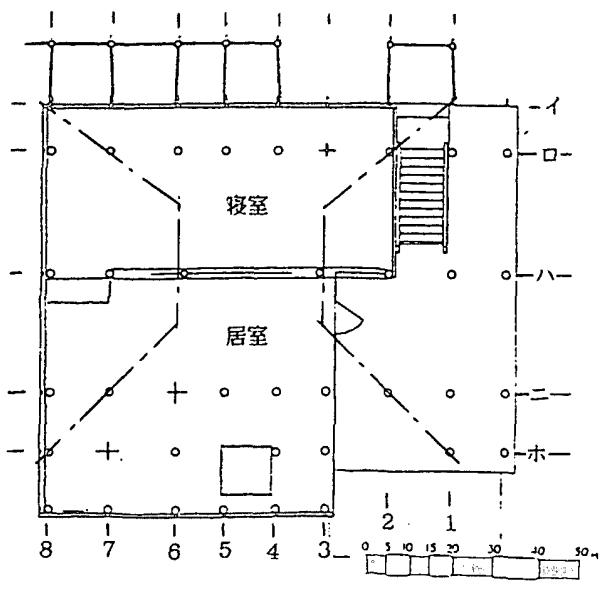

图4:曼喓16 平面圆

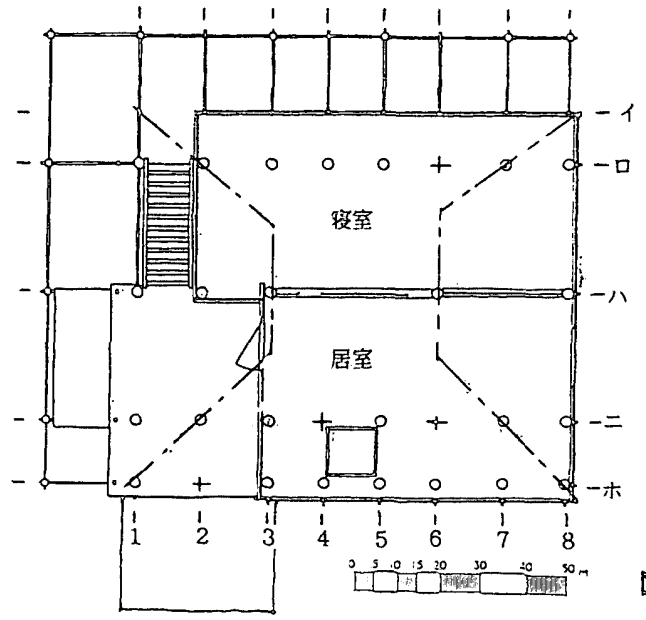

国5:曼饭 34 平面圆

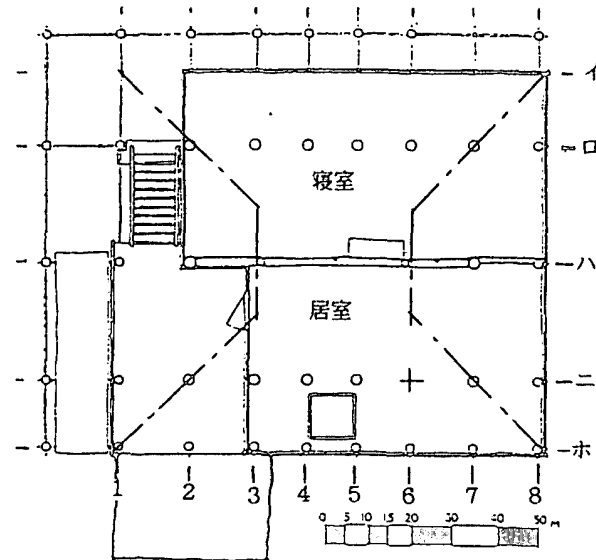

图6:曼婔27 平面图

\begin{tabular}{|c|c|c|c|c|c|c|c|c|c|c|c|c|c|}
\hline 村名 & \begin{tabular}{c|c}
$\mathrm{NO}$ \\
.
\end{tabular} & \begin{tabular}{l|l} 
图 \\
版
\end{tabular} & 建造年 & \begin{tabular}{|c|} 
再建 \\
年
\end{tabular} & 人 & 古杨 & 棟持 & $\begin{array}{l}\text { 任切壁位置 } \\
\text { (cm)は植木 } \\
\text { とのス" }\end{array}$ & 柱抜位置 & $\begin{array}{c}\text { 震室側 } \\
\text { 側柱 }\end{array}$ & 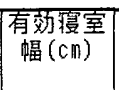 & $\begin{array}{l}\text { 任切壁 } \\
\text { 短束 }(\mathrm{cm})\end{array}$ & 備考 \\
\hline 量炸 & 20 & 2 & $\begin{array}{l}1910 \sim \\
1940\end{array}$ & & 5 & 無 & 柱 & 中 & & 無 & 300.0 & & $\begin{array}{l}\text { 部分補修は見られるが，軸部解体・变更は } \\
\text { 無し }\end{array}$ \\
\hline 曼炸 & 21 & & 1985 & & 5 & 有 & 角束 & 偏(97.0) & 可列全, $-4, \overline{6}, 7$ & 有 & 337.0 & 162.0 & 古材は前身住居のものかは不明 \\
\hline 盇炸 & 22 & & & 1984 & 4 & 峟 & 角束 & 编(75.0) & 咧全, $\sqrt{n-4,6,7}$ & 置 & 407.0 & 236.0 & 前身住居建造年代不明, 曼炸28に近傊 \\
\hline 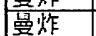 & 27 & 6 & 1937 & 1970 & $\frac{74}{5}$ & 有 & 柱 & 中 & $=-6, \$-2$ & 無 & 275.0 & & 材の補修は見られるが基本形態は変更せず \\
\hline 量曼炸 & 28 & 3 & 1984 & & $\frac{4}{4}$ & 無 & 角束 & 偏(110.0) & 0列全, $--3,4,6,7, \mathbf{f}-3$ & 峟 & 398.0 & 229.0 & 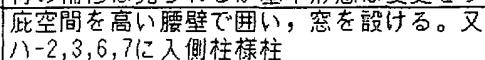 \\
\hline 曼炸 & 34 & 5 & 1970 & 1980 & 6 & 有 & 八角束 & 中 & $0-6, n-7,--4,6,6-2$ & 無 & 310.0 & & 二-5柱上部切断。 $\mathrm{h}-3,6$ 梁下まで入㑡柱桯柱 \\
\hline 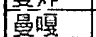 & 11 & & 1983 & & 4 & 無 & 角束 & 偏(164.5) & 列全, $-4,6,7$ & 学 & 344.0 & 184.0 & \\
\hline 嚗一 & 16 & 4 & 1983 & & 4 & 省 & 柱 & 中 & $0-3,--6, \$-2,5,7$ & 無 & 290.0 & & 枯列外側伀庇柱を立て室内化 \\
\hline 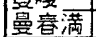 & $31=$ & 参 & & 1970 & $\frac{4}{4}$ & 要 & 無 & 中 & $-4,6, \$-4,6,7$ & 無 & & & 1994 に2 棟造筑 \\
\hline 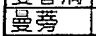 & 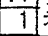 & 等 & 20c前 & 1974 & 6 & 青 & 柱 & 中 & $n-7,--6,7, \$-2,4,5,6,7$ & 無 & & & 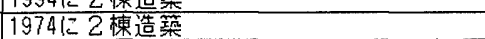 \\
\hline
\end{tabular}

玟1:咑毁住居りスト

（1996年 2 月29日原稿受理，1996年 8 月 22 日採用決定） 